\title{
The Conceptual model of user satisfaction for e- Learning Edmodo on Undergraduate students: A Preliminary study
}

\author{
Ridwan Daud Mahande ${ }^{1}$, Jasruddin ${ }^{2}$ \\ \{ridwandm@unismuh.ac.id ${ }^{1}$, jasruddin@unm.ac.id² \\ Muhammadiyah University of Makassar, Indonesia ${ }^{1}$, Makassar State University, Indonesia ${ }^{2}$.
}

\begin{abstract}
This study aims to gather various information for the formulation of a conceptual model of user satisfaction e-learning Edmodo. The preliminary study conducted through literature study and field study on students of Muhammadiyah University of Makassar, Indonesia. The study resulted in the integration of two models of the user acceptance technology, i.e., technology acceptance model (TAM) from Davis et al. and information system model (IS) success from DeLone \& McLean. The conceptual model of Edmodo e-learning user satisfaction generated in this research is a reference for model development and policy formulation in the implementation and development of Edmodo's ongoing e-learning content in universities.
\end{abstract}

Keywords: e-learning Edmodo, technology acceptance, information success, undergraduate program.

\section{Introduction}

Along with the development of technology and information, universities are required to integrate technology in education. The use of technology for education is the most appropriate, let alone most of today's students are generation $\mathrm{Y}$ and $\mathrm{Z}$ generation or better known as digital natives [1]. In connection with that, the use of technology in college is a wise decision and the most appropriate thing to do. The purpose of technology can do through the use of e-learning and its application to teaching and learning process. The significant advantage of e-learning is to support students and lecturers with some unique abilities such as interactivity, active search, physical closeness and mobility, independent learning and training, and techniques for acquiring active knowledge and lesson delivery through asynchronous and synchronous learning network models [2]. The benefits of e-learning can meet the requirements of learning in the modern era. Therefore, e-learning has created a high demand for higher education institutions [3].

Among the trends and needs of e-learning in universities, several applications that can be used to support e-learning are: learning management system (LMS) such as Moodle and learning social network (LSn) like Edmodo. In the study will only review LSn Edmodo, because this LSn plays an essential role in everyday life, especially in college. As a social networking site, Edmodo gives students the pleasure and convenience to learn according to learning objectives [4]. Edmodo's use strongly supported by a large number of faculty and

ICCSET 2018, October 25-26, Kudus, Indonesia

Copyright (C) 2018 EAI

DOI 10.4108/eai.24-10-2018.2280533 
students relying on mobile devices as the primary means of communication and using these devices to access social networking sites. In the field of education, universities should use this technology effectively.

Moreover, lecturers and students are currently looking for ways to improve teaching and learning process. Edmodo can be a smart and easy solution to ensure successful learning [5]. Edmodo has become one of the freest and widely used social learning platforms for students and lecturers, as it offers many features that enable a variety of virtual interaction and activity modes [6]. The results of research [7] indicating that the percentage of Edmodo e-learning application users is 34\% larger, compared to other applications such as Moodle 7\%, journal $6 \%$, academics and 5\%, Library $4 \%$. Edmodo is endearing and has the potential to change the way of learning, stimulate motivation and encourage students to move forward.

Ironically, on a contextual basis at the University of Muhammadiyah Makassar, Indonesia, Edmodo has been introduced even used but did not last long. The results of the observations showed the lack of use of Edmodo by some students to improve the self-learning experience. Due to the slow adoption of digital on campus, plus the lack of self-awareness of students to advance in the era of learning social media. More specifically, the results of limited interviews conducted by researchers to students to obtain information that varies, including the lack of use of Edmodo due to the quality of information presented, the learning services offered, the level of ease of the system is still not felt by some students and the level of usefulness in learning. This information confirms the need for preliminary research to identify or track where the student is concerned with the satisfaction of the implementation of this Edmodo service. This study will examine in depth the external factors of usability and ease of attitudes and intentions to receive Edmodo. Assessing these acceptance factors to generate user-defined (student) satisfaction factors described as conceptual models, and will then be analyzed in different articles.

User satisfaction is the user's subjective judgment of the found information compared to expected details that exceed its standard internal rating [7]. The better or higher the Edmodo elearning factors affect, the higher the user's satisfaction in using Edmodo-based e-learning. Therefore, the investigation of the determinants of user satisfaction is essential to do. Hopefully, the results will present an effort to expand Edmodo-based e-learning opportunities for students and to foster a learning environment that is responsible for their learning.

In this connection, a satisfaction-acceptance model approach needed as a solution to the research problem. Because of its emphasis on the user satisfaction model of Edmodo application technology, the technology acceptance model is considered to be the most appropriate to be used as an effort to generate a user satisfaction model of Edmodo e-learning. One of the most widely used technology acceptance models is the Technology Acceptance Model (TAM), which offers a theoretical basis for user acceptance and information technology usage behavior. The TAM model identifies perceived usefulness as the level of work improvement after system implementation. Perceived ease of use is the user's perception of comfort in adopting the system. Both of these factors influence attitude toward technology/application and further influence individual trust and behavior and satisfaction when fostering a system [3].

Furthermore, Edmodo-based e-learning systems derived from user satisfaction maximized unless all members of an organization are affected to use this system effectively. Another focus in this research is to see how the system context can influence users to use Edmodo-based e-learning system by looking at external variables of DeLone \& McLean's information system model, namely: information quality, system quality and service quality as a construct to user satisfaction [8]. The e-learning system creates information communicated 
to users who are then affected or not affected by the system. The answer to whether the user changed or not can reflect by the actual use of the student system.

Previous studies have used the adoption of information technology such as the TAM model, the Unified Theory of Acceptance and the Use of Technology (UTAUT) and the DeLone \& McLean model to explore Edmodo's behavioral and user-based e-learning patterns. Some of these studies have traced the perception, cognitive style, obstacles and drivers of Edmodo-based e-learning adoption [9]; [10]; [11]; [12]. Unlike previous research, this study integrates TAM model variables with DeLone \& McLean model variables. The perceived ease of use and perceived usefulness variables derived from the TAM model positioned as internal variables. While the variable information quality, system quality, and service quality are taken from the DeLone \& McLean model posted as an external variable. External and internal variables aim to predict user satisfaction of Edmodo-based e-learning system. More specifically, the selection of variables based on consideration of the location of the research and previous studies, where these variables significantly affect user satisfaction in the use of elearning Edmodo. Then, this study re-tested these factors/variables in different contexts, i.e., at universities, Muhammadiyah University of Makassar, Indonesia.

This study contributes to indicate factors that contribute to the satisfaction of Edmodobased e-learning use and presents an alternative conceptual model of Edmodo's e-learning user satisfaction in universities. Thus, this research can use as a reference for the development of elearning satisfaction model and for e-learning policy maker in the framework of implementation and development of Edmodo-based e-learning content that is sustainable in Higher Education.

\section{$2 \quad$ E-learning}

E-learning is defined as a dynamic learning environment through the use of the Internet to improve the quality of learning. E-learning has a positive impact on lecturers and students, as it positively affects the duration of attention, the tenacity of education and training, and attitudes toward collaboration and interaction [2]. More broadly, [8] outlines some significant trends related to the advantages of e-learning, including (1) student-centered, (2) non-linear and self-directed, (3) face to face, (4) long distance, and blended-distance, (5) approach will be dominant in the future, (6) life-long learning, academic emphasis shifts from course completion to achieving competence, (7) the role of college turned into the course designer, tutor, etc., (8) decreased workload of lecturers, (9) primarily when working with learning, and (10) management systems or collaborative environment and online conferences.

E-learning has now become an accepted part of student life, especially in college. However, students will have their own opinions and feelings about the usefulness of elearning systems to replace or enhance the learning approach. Some lecturers and students argue that e-learning is just a web-based lesson delivery. Others will praise e-learning because it's easy to learn a few things quickly. Most colleges today offer some form of e-learning as a tool to improve the quality of teaching. Therefore, there is a need for e-learning materials that must be well designed [8]. Learning social network is a solution for a system with complete feature and able to support good e-learning material. 


\section{E-Learning Social Network (Lsn) Edmodo}

Edmodo was founded in Chicago Illinois by Nic Borg, Jeff O'Hara, Crystal Hutter with the goal of bridging the gap between how students move about every day by studying at school [13]. Edmodo is very simple and almost similar to Facebook, so it's called Facebook for school. It informed so that students are eager to learn and keep it in an exciting environment [5]. According to Kongchan, Edmodo is intended to make room for lecturers, students, and even parents to monitor and maximize teaching and learning [14]. In particular, it gives students the opportunity to practice lessons outside the classroom [15].

Edmodo is a free and secure education learning network that is used to provide a simple way for lecturers to create and manage an online classroom community and allows students to connect and work with lecturers wherever and whenever [4]. Lecturers with students, students, and students can communicate through private and public messages, send notices and announcements, awards, assignments, discussions, polls, and quizzes, assign value, share resources, organize class schedules and create small groups for learning projects. Also, students can easily connect to lecturers, post questions, upload files and link (e-library), submit assignments, take quizzes, collaborate, share, discuss, and participate in elections [5].

Edmodo is a social platform for education, where interaction processes work online, share resources, engage in conversation, develop skill and argumentative communication with ease without hesitation [12]. It is this Edmodo feature that makes learning more accessible, convenient and more interesting. Moreover, students who feel embarrassed even stress to speak verbally in front of the class. Edmodo learns beyond the classroom by providing a safe and comfortable place for lecturers and students to connect and collaborate, whenever and wherever. Lecturers and students can face each other through forums, chats and video conferences to share useful ideas, problems, and tips. An ordinary lecturer assigns and classifies student work in Edmodo; students can get help from all classes in Edmodo. Also, parents can attend classes to observe the process that their child is doing in learning. Lecturers and students should utilize Edmodo ability in supporting classes online lectures.

\section{Method}

A preliminary study conducted through literature studies and field studies. Literature study by studying research journal and books that are relevant to research problems. Field study through observation (direct observation) without the help of standard equipment, which was carried out at Muhammadiyah University of Makassar, Indonesia. The data obtained were analyzed descriptively, namely describing, explaining and providing understanding and explanation.

\section{User Acceptance and User Satisfaction Models}

TAM developed from Theory of Reasoned Action (TRA) by Fishbein \& Ajzen offers a theoretical basis for user acceptance and behavioral use of information technology. The TAM model focuses on predicting and assessing the user's propensity to accept technology. The TAM model proposed by Davis examines the relationship between three critical variables: 
perceived usefulness, perceived ease of use and attitude towards actual usage. This theoretical framework is very appropriate to predict the learning satisfaction of e-learning Edmodo. Will be reviewed by the results of the study indicating that the variables in TAM proved to affect the satisfaction of learners [3] significantly.

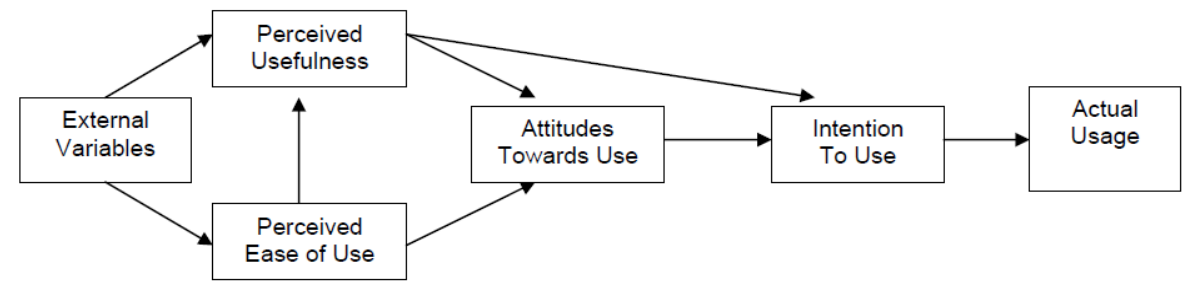

Fig. 1. TAM Model [16].

There are two central beliefs, perceived usefulness (PU) and perceived ease use (PEOU) that cause a person's behavior to adopt a system such as e-learning Edmodo. Furthermore, Davis (1989) states PU refers to the extent to which a person believes that using a particular system will improve his performance or work. PEOU applies to the area to which a person believes that using a specific system will be free of great difficulty or effort. Attitude towards of-use (ATU) refers to the area to which an individual evaluates and associates the target system with its work. Davis (1989) explains that user trust is directly related to the use of technology, attitudes, and intentions to use technology. Attitudes toward behavior refer to the judgment of people that doing behavior is good or bad. Perceived usefulness has a stronger relationship with use than other variables. Also, one adopts the technology if it forgot convenient, useful and socially desirable although it is unpleasant to use the technology [17].

Both of these factors affect user attitudes toward the software and further affect the trust and behavior of individuals when adopting this system. Specifically, the application of the TAM model aims to predict how far the usability and easiness variables affect student acceptance of Edmodo based e-learning. The more students feel the usefulness and ease of using e-learning Edmodo, the higher the student's acceptance of Edmodo-based e-learning. The explanation of [3] the perceived usefulness of students in the e-learning system defined as the perception of the degree of an increased learning effect. Meanwhile, the perceived ease of use in the e-learning system is the student's perception of easiness in adopting e-learning systems.

The success of an information system according to the theory mentioned above also comes from the measurement of the quality of the method implemented by the information center in collecting and processing information, measuring the suitability between the quality of information content available to the user's needs, and the measurement of the quality of its services. The success of these three factors can affect students always to use the facilities provided by information services as well as e-learning Edmodo. The increasing use of facilities offered by Edmodo e-learning services is an indicator for the satisfaction of information perceived by students. Ultimately, it affects student behavior and also affects the success of the information system. Student satisfaction, in general, can be defined as student happiness associated with various aspects of the service it receives. In this case, satisfaction is a factor directly affected by the service element. When the initial study conducted, it appears that many factors influence student satisfaction. 
These factors are as mentioned by [18]: interaction in online and face-to-face classes, feedback, student and lecturer behavior, activities, materials, online discussions, instructional and technical support, technological features, student learning styles, online discussion, selfefficacy, knowledge and skills, and demographic characteristics. To predict the factor, DeLone and McLean through information success model (IS) stated that the success of information system through technology aspect determined by system quality, information quality, intention to use, and user satisfaction. Then Delone \& McLean updated the model by adding service quality as a determinant of information success, referring to personal support from technology platforms [19].

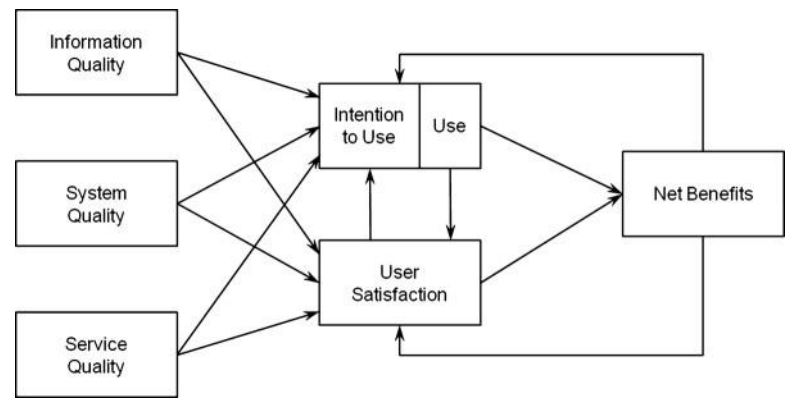

Fig. 2. IS Success Model [20].

According to [8], information quality, system quality, and service quality are the external factors that determine user satisfaction with the e-learning system. Edmodo's e-learning system creates information communicated to users, then influenced or unaffected by the system. The answer to whether the user is affected or not can reflected by the actual use of the student system. This research will explore further external variables that affect the utilization of Edmodo-based e-learning to support e-learning learning in education. The results of the discovery of external and internal variables that significantly influence the usage of Edmodo used as the basis for the development of Edmodo's useful e-learning user satisfaction model for e-learning learning. The following presented the results of relevant research studies in Table 1.

Table 1. Relevant Research Studies.

\begin{tabular}{|c|c|c|}
\hline Researchers & Variable & Key results \\
\hline [7] & $\begin{array}{l}\text { service quality, information quality, user } \\
\text { participation, benefit, user satisfaction }\end{array}$ & user participation, benefit \\
\hline$[21]$ & $\begin{array}{l}\text { subjective norm, experience, perceived } \\
\text { enjoyment, computer anxiety, perceived } \\
\text { usefulness, self-efficacy, technology innovative. }\end{array}$ & $\begin{array}{l}\text { perceived usefulness, } \\
\text { technologically innovative, } \\
\text { perceived enjoyment, self-efficacy }\end{array}$ \\
\hline [1] & $\begin{array}{l}\text { Perceived ease of use, perceived usefulness, } \\
\text { attitude }\end{array}$ & Attitude \\
\hline$[22]$ & $\begin{array}{l}\text { collaboration, usefulness, instructor support, } \\
\text { self-confidence, }\end{array}$ & $\begin{array}{l}\text { collaboration, usefulness, instructor } \\
\text { support }\end{array}$ \\
\hline [11] & $\begin{array}{l}\text { Perceived usefulness, perceived ease of use, } \\
\text { attitude toward Edmodo, facilitating conditions, } \\
\text { computer self-efficacy, subjective norm, } \\
\text { technological complexity, behavior intention }\end{array}$ & $\begin{array}{l}\text { Perceived usefulness, perceived ease } \\
\text { of use, computer self-efficacy, } \\
\text { subjective norm, behavior intention }\end{array}$ \\
\hline
\end{tabular}




\begin{tabular}{|c|c|c|}
\hline Researchers & Variable & Key results \\
\hline [19] & $\begin{array}{l}\text { User perceived satisfaction, use, individual } \\
\text { impact, individual collectivism, organizational } \\
\text { impact }\end{array}$ & User perceived satisfaction \\
\hline [23] & $\begin{array}{l}\text { performance expectancy, effort expectancy, } \\
\text { social influence, \& facilitating condition, price } \\
\text { value, habit, hedonic motivation }\end{array}$ & $\begin{array}{l}\text { performance expectancy, price } \\
\text { value, habit }\end{array}$ \\
\hline [17] & $\begin{array}{l}\text { achievements, anxiety, perceived usefulness, } \\
\text { perceived ease of use, attitude, subjective norm, } \\
\text { perceived behavior control, satisfaction, } \\
\text { continued intention, self-efficacy, facilitating } \\
\text { conditions }\end{array}$ & $\begin{array}{l}\text { perceived ease of use, attitude, } \\
\text { satisfaction and self-efficacy }\end{array}$ \\
\hline [2] & $\begin{array}{l}\text { educational quality, service quality, technical } \\
\text { system quality, content \& information quality, } \\
\text { perceived ease of usefulness, perceived ease of } \\
\text { use, satisfaction, intention to use }\end{array}$ & $\begin{array}{l}\text { technical system quality, content } \& \\
\text { information quality, perceived ease } \\
\text { of usefulness }\end{array}$ \\
\hline [24] & $\begin{array}{l}\text { perceived quality, quality disconfirmation, value } \\
\& \text { value disconfirmation, disconfirmation } \\
\text { usability }\end{array}$ & $\begin{array}{l}\text { perceived quality, quality } \\
\text { disconfirmation, value } \& \text { value } \\
\text { disconfirmation, }\end{array}$ \\
\hline [12] & academic results \& perceived usefulness & academic results \\
\hline [8] & $\begin{array}{l}\text { organizational context, system context, } \\
\text { cognitive styles, usage, satisfaction. }\end{array}$ & $\begin{array}{l}\text { organizational context, system } \\
\text { context }\end{array}$ \\
\hline [9] & $\begin{array}{l}\text { Perceived usefulness, perceived ease of use, } \\
\text { instructor }\end{array}$ & $\begin{array}{l}\text { Perceived usefulness, perceived ease } \\
\text { of use, instructor }\end{array}$ \\
\hline
\end{tabular}

The relevant research confirms that the TAM model \& IS model has been widely used and developed to track the acceptance of information systems/technologies, especially elearning in some countries including Indonesia. However, the construct development of the TAM model and the IS model varies according to the research context. In particular, the relevant research study also shows that e-learning through the TAM model approach and IS model in some universities in Indonesia very poorly done. Moreover, a study that integrates the TAM model with the IS model to investigate user satisfaction e-learning Edmodo in universities, especially in the city of Makassar. Contextually, e-learning Edmodo through TAM \& IS model approach in Unismuh Makassar has never been done. This research will integrate the TAM model approach \& IS model in investigating Edmodo e-learning acceptance factor/variable and produce Edmodo e-learning user satisfaction model.

The selection of constructs or variables of the TAM model and the IS model based on the results of relevant research studies. The results of relevant research studies on the relationship between TAM \& IS model variables confirmed that service quality, information quality, system quality significantly influenced user satisfaction [19]; [7]; [2]; [21]. Perceived usefulness affects user satisfaction [9]; [21]; [22]; [11]. Perceived ease ouse gives influence to user satisfaction [9]; [17]; [2]; [11]. Accordingly, the selection of variables in this study based on the assertion of some researchers by looking at the level of significance of research variables, then adjusting to the conditions or needs of e-learning user satisfaction research Edmodo in Unismuh Makassar. 


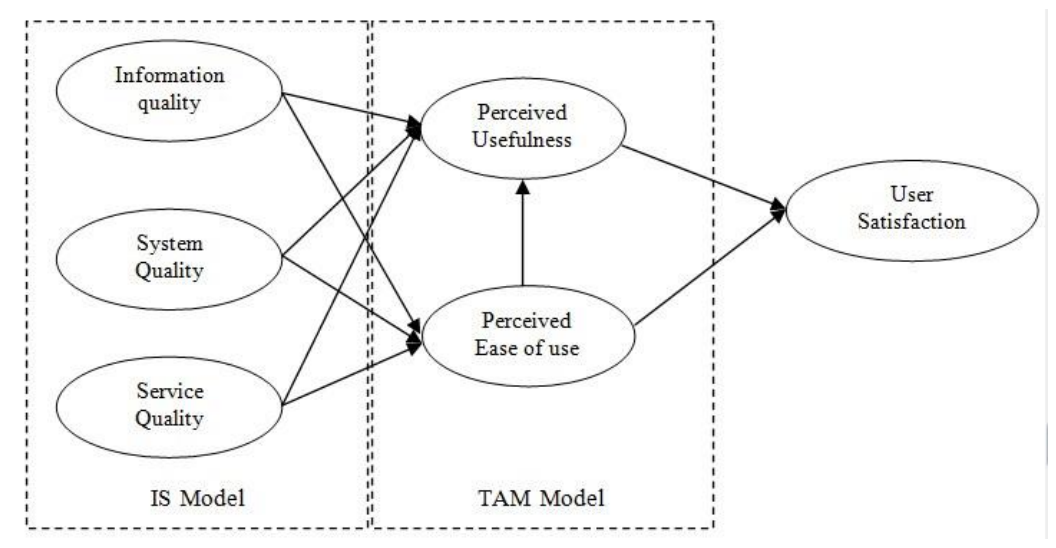

Fig. 3. A conceptual model of Edmodo e-learning user satisfaction.

\section{Conclusion, Limitations and Future Research}

User satisfaction model is fundamental to know how far e-learning social network Edmodo acceptable and give satisfaction to the student. To understand this, we need a conceptual model that presents the relationship between variables that affect the level of student satisfaction with e-learning Edmodo. Edmodo's conceptual model of e-learning integrates two models of technology acceptance: the technology acceptance model (TAM) from Davis et al. and information success model (IS) from Delone \& McLean. Edmodo's conceptual model of e-learning user satisfaction emphasizes two key construct variables of TAM, namely: perceived usefulness and perceived ease of use. While the IS model underlines three key variables, namely: information quality, system quality, and service quality. This preliminary study contributes to the factors or variables that contribute to Edmodo's e-learning user satisfaction and provides an alternative conceptual model of Edmodo e-learning user satisfaction.

This preliminary study only examines the satisfaction model in general, then takes two models as the primary reference that represents each variable. The conceptual model based on the level of significance of previous research variables and limited interviews has not yet arrived at the statistical test of variables. Subsequent research can use, develop and test models according to the context in which study is conducted.

\section{Acknowledgments}

The author would like to thank the Research Institute and Postgraduate Program of Universitas Negeri Makassar for facilitating and funding this research. Thanks also to the technical research team 


\section{References}

[1] Z. Hussein, "Leading to Intention: The Role of Attitude in Relation to Technology Acceptance Model in E-Learning," Procedia Comput. Sci., vol. 105, pp. 159-164, 2017.

[2] H. Mohammadi, "Investigating users' perspectives on e-learning: An integration of TAM and IS success model," Comput. Hum. Behav., vol. 45, pp. 359-374, Apr. 2015.

[3] P.-C. Sun, R. J. Tsai, G. Finger, Y.-Y. Chen, and D. Yeh, "What drives a successful e-Learning? An empirical investigation of the critical factors influencing learner satisfaction," Comput. Educ., vol. 50, no. 4, pp. 1183-1202, May 2008.

[4] K. Balasubramanian, V. Jaykumar, and L. N. Fukey, "A Study on 'Student Preference towards the Use of Edmodo as a Learning Platform to Create Responsible Learning Environment,"” Procedia - Soc. Behav. Sci., vol. 144, pp. 416-422, Aug. 2014.

[5] S. T. Alshawi and F. A. Alhomoud, "The Impact of Using Edmodo on Saudi University EFL Students' Motivation and Teacher-Student Communication," Int. J. Educ., vol. 8, no. 4, p. 105, Dec. 2016.

[6] F. Dewi, "EDMODO: A Social Learning Platform for Blended Learning Class in Higher Education," Res. Educ. Technol. Pedagogy Technol. J. SEAMEO-SEAMOLEC, vol. 11, no. 2, 2014.

[7] Ramadiani, Azainil, U. Haryaka, F. Agus, and A. H. Kridalaksana, "User Satisfaction Model for e-Learning Using Smartphone,” Procedia Comput. Sci., vol. 116, pp. 373-380, 2017.

[8] N. H. Zamzuri, M. Shahrom, E. S. Kasim, H. M. Nasir, and M. N. Mamat, "The Role of Cognitive Styles in Influencing the users' Satisfaction on E-Learning System," Procedia - Soc. Behav. Sci., vol. 67, pp. 427-435, Dec. 2012.

[9] M. Thongmak, "Social Network System in Classroom: Antecedents of Edmodo (C) Adoption," J. E-Learn. High. Educ., pp. 1-15, Aug. 2013.

[10] K. G. Tileng, "Penerapan Technology Acceptance Model pada Aplikasi Edmodo di Universitas Ciputra Surabaya menggunakan Analisis Jalur," J. Inform. Dan Sist. Inf., vol. 1, no. 1, pp. 28-37, 2015.

[11] Ö. F. Ursavaş and I. Reisoglu, "The effects of cognitive style on Edmodo users' behaviour: A structural equation modeling-based multi-group analysis," Int. J. Inf. Learn. Technol., vol. 34, no. 1, pp. 31-50, Jan. 2017.

[12] A. Gómez, A. A. Magreñán, and L. Orcos, "UX of Social Network Edmodo in Undergraduate Engineering Students," Int. J. Interact. Multimed. Artif. Intell., vol. 3, no. 4, p. 31, 2015.

[13] A. B. Hakim, "Efektifitas Penggunaan E-Learning Moodle, Google Classroom Dan Edmodo," STATEMENT Inf. Syst. Technol. Manag., vol. 2, no. 1, 2016.

[14] P. Purnawarman, S. Susilawati, and W. Sundayana, "The use of Edmodo in teaching writing in a blended learning setting,” Indones. J. Appl. Linguist., vol. 5, no. 2, p. 242, Jan. 2016.

[15] the Department of Western Languages, Faculty of Humanities and Social Sciences, Burapha University, Chon Buri, Thailand and R. Warawudhi, "The Evaluation of Edmodo in Business Reading Class," Int. J. Inf. Educ. Technol., vol. 7, no. 2, pp. 153-158, 2017.

[16] F. D. Davis, R. P. Bagozzi, and P. R. Warshaw, "User acceptance of computer technology: a comparison of two theoretical models," Manag. Sci., vol. 35, no. 8, pp. 982-1003, 1989.

[17] R. Cakır and E. Solak, "Attitude of Turkish EFL Learners towards e-Learning through Tam Model," Procedia - Soc. Behav. Sci., vol. 176, pp. 596-601, Feb. 2015.

[18] R. Yilmaz, "Exploring the role of e-learning readiness on student satisfaction and motivation in flipped classroom," Comput. Hum. Behav., vol. 70, pp. 251-260, May 2017.

[19] M. Aparicio, F. Bacao, and T. Oliveira, "Cultural impacts on e-learning systems' success," Internet High. Educ., vol. 31, pp. 58-70, Oct. 2016.

[20] W. H. Delone and E. R. McLean, "The DeLone and McLean model of information systems success: a ten-year update," J. Manag. Inf. Syst., vol. 19, no. 4, pp. 9-30, 2003.

[21] C.-T. Chang, J. Hajiyev, and C.-R. Su, "Examining the students' behavioral intention to use elearning in Azerbaijan? The General Extended Technology Acceptance Model for E-learning approach," Comput. Educ., vol. 111, pp. 128-143, Aug. 2017. 
[22] E. Yunkul and S. Cankaya, "Students' Attitudes Towards Edmodo, a Social Learning Network: A Scale Development Study,” Turk. Online J. Distance Educ., vol. 18, no. 2, pp. 16-29, 2017.

[23] S. Assegaff, "Analisis Perilaku Penerimaan EDMODO pada Perkuliahan Dengan Model UTAUT,” J. Teknol. Dan Sist. Inf., vol. 2, no. 3, pp. 1-10, 2016.

[24] F. A. de M. Pereira, A. S. M. Ramos, M. A. Gouvêa, and M. F. da Costa, "Satisfaction and continuous use intention of e-learning service in Brazilian public organizations," Comput. Hum. Behav., vol. 46, pp. 139-148, May 2015. 